УДК 669.713.7:67.08

\title{
Low Voltage PFC Emission from Aluminium Cells
}

\author{
Jomar Thonstad $^{\mathrm{a}^{*}}$ and Sverre Rolseth ${ }^{\mathrm{b}}$ \\ ${ }^{a}$ Norwegian University of Science and Technology \\ Trondheim, NO-7491, Norway \\ ${ }^{b}$ SINTEF Materials and Chemistry \\ 4 Strindveien, Trondheim, NO-7465, Norway
}

Received 28.02.2017, received in revised form 14.03.2017, accepted 23.03.2017

It is well known that the perfluorocarbon (PFC) gases $C F_{4}$ and $C_{2} F_{6}$ are being emitted during anode effects in aluminium cells. These PFC compounds are very strong greenhouse gases, and the aluminium industry has made great efforts to reduce these emissions. From 1990 to 2008 a 90\% reduction in PFC emissions has been achieved. However, during the last few years we have received new alarming information, mainly from the Chinese aluminium industry, that there is an almost continuous emission of PFC gases from aluminium potlines even in the absence of anode effects, and it accounts for 10 to $90 \%$ of the total PFC emissions, the median being 70\%. They named it "Non-anode effect PFC emissions". This information has later been confirmed from several sources, so it seems to be a universal problem. To our knowledge it was first detected by the late Warren Haupin of Alcoa in 1995, but apparently it was not taken seriously at that time. Now we know better. A recent report from Alcoa indicates that whereas low voltage PFC emissions were observed in all prebake plants being investigated, it was not detected in two Soderberg potlines. Possible reasons for that will be discussed.

Keywords: aluminium electrolysis, anode effect, PFC perfluorocarbons.

DOI: $10.17516 / 1998-2836-0003$.

(C) Siberian Federal University. All rights reserved

* Corresponding author E-mail address: Jomar.Thonstad@ntnu.nu 


\title{
Выделение перфторуглеродов \\ в алюминиевом электролизере \\ при низком напряжении
}

\author{
Йомар Тонстэд ${ }^{\mathrm{a}}$, Сверре Ролсет ${ }^{\sigma}$ \\ ${ }^{a}$ Норвежский университет науки и технологии \\ Норвегия, NO-7491, Trondheim \\ ${ }^{6}$ SINTEF Materials and Chemistry \\ Норвегия, NO-7465, Trondheim, Strindveien, 4
}

\begin{abstract}
Известно, что при анодных эффектах на алюминиевых электролизерах выделяются газообразные перфторуглероды $\mathrm{CF}_{4}$ и $\mathrm{C}_{2} F_{6}$. Данные соединения являются парниковыми газами, и в алюминиевой промышленности проводятся активные мероприятия по их сокращению. С 1990 по 2008 г. сокращение выбросов ПФУ достигло 90 \%. Однако, в последние годы была получена сенсачионная информация, главным образом от китайской алюминиевой промымленности, что непрерывные выбросы газообразных ПФУ на сериях электролиза алюминия не прекращаются даже в отсутствие анодных эффектов, составляя от 10 до 90 \% от общего количества выбросов со срединным значением 70 \%. В китайской алюминиевой промымленности это назвали «Выбросы ПФУ, не связанные с анодным эффектом». Данная информация была впоследствии подтверждена несколькими компаниями в разных странах, поэтому представляется, что данная проблема является всеобщей. Впервые это было обнаружено Уорреном Хопином (WarrenНаиріn), сотрудником Alcoа в 1995 2., но в то время это не было принято всерьез. В настоящее время мы знаем больше. В недавнем сообщении Alсоа указывается, что низковольтные выбросы ПФУ обнаружены на всех исследуемых заводах электролиза с обожженными анодами и не зафиксированы в двух сериях электролизеров с анодами Содерберга. Возможные причины такого явления будут обсуждаться в статье.
\end{abstract}

Ключевые слова: алюминиевый электролизер, анодный эффект, перфторулероды (ПФУ).

\section{Introduction}

During the last 20 years strong efforts have been made in order to reduce the emission of PFC (perfluorocarbon) gases from the aluminium industry. These gases are being emitted during the so-called anode effect, which occurs when the concentration of dissolved alumina in the bath gets too low $(<0.5-2 \mathrm{wt} \%)$. The cell voltage then rises abruptly to $15-40 \mathrm{~V}$, and an anode effect is on [1]. In order to extinguish anode effects, alumina is being fed, and the bath is being agitated in various ways, e.g. by inserting wooden poles or by repeatedly raising and lowering the anode beam.

The PFC emissions from any given plant are being reported to the national environmental protection agency. It is being calculated by taking the time on anode effect multiplying it by an empirical factor, named "the slope". The units are ton $\mathrm{CO}_{2}$ eq./ton Al. The time on anode effect is normally recorded as the time 
above $8 \mathrm{~V}$ cell voltage. This data is being recorded due to the fact that the $\mathrm{PFC}$ gases, $\mathrm{CF}_{4}$ and $\mathrm{C}_{2} \mathrm{~F}_{6}$, are very potent greenhouse gases, contributing to global warming. $\mathrm{CF}_{4}$ is 6500 times and $\mathrm{C}_{2} \mathrm{~F}_{6}$ is 9200 times stronger greenhouse gases than $\mathrm{CO}_{2}$. The initiative for this reporting comes from "The United Nations Intergovernmental Panel on Climate Change" (IPCC), and the data are being collected and reported by the International Aluminium Institute (IAI) in London. IAI has reported that the average PFC emissions have been reduced from close to 5 ton $\mathrm{CO}_{2}$ eq./ton $\mathrm{Al}$ in 1990 down to 0.70 in 2010, and a goal of 0.34 in set for 2020 [2].

This remarkable achievement is the result of impressive efforts made by the aluminium industry over the years by introducing new technology and improved cell control and cell operation. This is really a success story. But is it the whole story?

Apparently it is not the whole story. In recent years there have been several reports [2-5] showing that under certain circumstances, PFC emissions are also being detected during normal operation when there is noongoing anode effect in thepotline. It has been named "non-anode effect PFC emissions" or simply "low voltage PFC emissions".

As far as we know, this phenomenon was first recorded by the late Warren Haupin of Alcoa in an internal Alcoa report in 1995 [6]. As shown below the normal cell voltage (3.7-4.5 V) is high enough to permit PFC emissions during certain operating conditions, but at that time (the 1990ies) we tended to think that although being possible, Haupin's observation must have been a very extraordinary and rare event.

Now we know better, because several reports have come out telling the same story, i.e. that PFC emissions during normal operation is a severe problem, which the industry is facing. It has been reported that it tends to occur during anode changing and at the end of underfeeding periods [5]. According to Chinese data, it can amount to 34-93 percent of the total PFC emissions [3-4], the average being 70\% [2]. As shown in the following, an explanation of this phenomenon can be based on laboratory studies of the initiation of anode effects.

\section{The critical current density}

In the normal cell reaction the anode product is $\mathrm{CO}_{2}$,

$$
\mathrm{Al}_{2} \mathrm{O}_{3}+3 / 2 \mathrm{C}=2 \mathrm{Al}+3 / 2 \mathrm{CO}_{2} \quad \mathrm{E}=-1.18 \mathrm{~V}
$$

By alumina depletion the cryolite-based solvent may start to decompose,

$$
\begin{aligned}
& \mathrm{Na}_{3} \mathrm{AlF}_{6}+3 / 4 \mathrm{C}=3 / 4 \mathrm{CF}_{4}+3 \mathrm{NaF} \mathrm{E}=-2.42 \mathrm{~V} \\
& \mathrm{Na}_{3} \mathrm{AlF}_{6}+\mathrm{C}=\mathrm{Al}+1 / 2 \mathrm{C}_{2} \mathrm{~F}_{6}+3 \mathrm{NaF} \mathrm{E}=-2.68 \mathrm{~V}
\end{aligned}
$$

As shown in Fig. 1, when increasing the imposed voltage on a graphite anode, the current density increases up to a peak value, named the "critical current density". Thereafter the current density drops back to a very low value $\left(\approx 0.04 \mathrm{~A} / \mathrm{cm}^{2}\right)$ at a voltage above $3 \mathrm{~V}$. This voltage is high enough to sustain the formation of PFCs according to reactions (2) and (3). Apparently, this is exactly what happens. In a paper published in 1974 [7] we showed that in the potential range 3-3.4 $\mathrm{V}$ the anode gas from a cryolite melt contained $10-30 \% \mathrm{CF}_{4}$ (at that time we did not have the means to detect $\mathrm{C}_{2} \mathrm{~F}_{6}$ ). Melts richer in alumina would probably show lower $\mathrm{CF}_{4}$ contents, but not zero. 


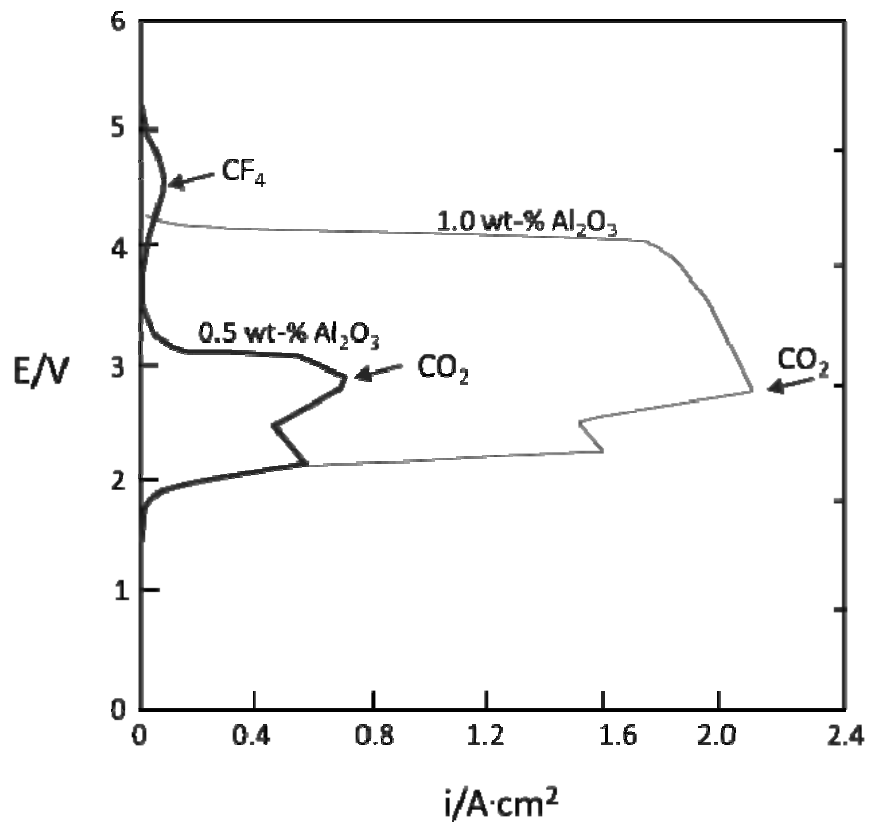

Fig. 1. Linear potential sweep curves obtained with graphite anodes in cryolite melts at $1020{ }^{\circ} \mathrm{C}$ [7]. Curve I: 0.5 wt $\% \mathrm{Al}_{2} \mathrm{O}_{3}$, Curve II: 1 wt $\% \mathrm{Al}_{2} \mathrm{O}_{3}$

\section{The effect of local alumina depletion}

If we consider an industrial cell with multiple prebaked anodes, we may have the case that one or more anodes are subjected to alumina depletion. The current density on such an anode then decreases due to a shortage of oxygen ions. This implies that the ohmic voltage drop through the anode assembly and the adjoining bath decreases, and the anode potential referred to aluminium rises accordingly. It may now pass the critical current density, marked by $\mathrm{CO}_{2}$ in Fig. 1, and enter into the low current density/high voltage range shown to the left in the figure (marked by $\mathrm{CF}_{4}$ ). The anode may remain in this mode until a fresh supply of dissolved alumina arrives.

In Fig. 2 this situation isillustrated byshowing twoprebake anodes of which one is sustaining normal electrolysis producing $\mathrm{CO}_{2}$, and the other is "starved" and in addition produces PFC gas (note the voltage scales on top of the figure). The real situation may be more complicated than indicated here, but this treatment gives at least a plausible explanation of what has been observed.

During anode effect the gases $\mathrm{CF}_{4}$ and $\mathrm{C}_{2} \mathrm{~F}_{6}$ are being formedon all anodes in a cell, according to reactions (2) and (3). The formation of $\mathrm{COF}_{2}$ and $\mathrm{C}_{3} \mathrm{~F}_{6}$ during anode effect have also been reported [3, 8]. $\mathrm{COF}_{2}$ is unstable and decomposes $\left(2 \mathrm{COF}_{2}+\mathrm{C}=2 \mathrm{CO}+\mathrm{CF}_{4}\right)$. A typical anode gas composition during an anode effect can be: $5-20 \% \mathrm{CF}_{4}\left(+<1 \% \mathrm{C}_{2} \mathrm{~F}_{6}\right), 10-20 \% \mathrm{CO}_{2}, 60-70 \% \mathrm{CO}$.

Some general observations on low voltage PFC emissions can be summarized as follows:

- It tends to be initiated towards the end of underfeeding periods and by anode change.

- It can be observed as low background PFC emissions during normal electrolysis (no anode effect).

- It was first observed by W. Haupin (internal Alcoa report, 1995).

- A strongly renewed focus in recent years with several reports [3, 9-15]. 

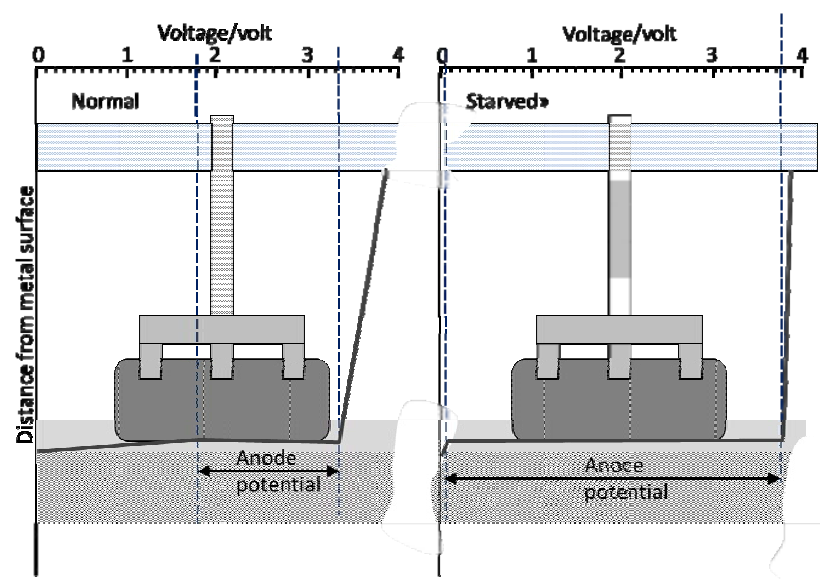

Fig. 2. Schematic presentation of the voltage profile between the cathode and the anode bar for one anode drawing normal current (left; anodic polarization voltage $\sim 1.7 \mathrm{~V}$ ) and one anode drawing low current (right; anodic polarization voltage $\sim 3.8 \mathrm{~V}$ )

- According to Chinese data for large prebake cells, the low voltage PFC emissions range from 10 to $90 \%$ of the total PFC emissions, the median being $70 \%$ [2-4].

- The emitted PFC gases are the same as during normal anode effects, namely CF4 and C2F6.

- Recent Alcoa findings show that this phenomenon does not seem to occur on Soderberg cells [15].

If it is so that alumina depletion is the cause of this problem, one can contemplate ways to abate it. The following measures may be considered:

1. Improve the alumina distribution in the cells (install more feeders?).

2. Continuous monitoring of the current distribution on all anodes, using available automatic devices [16].

3. Run at higher average alumina concentration. Today the alumina concentration is squeezed, because it is known that higher current efficiency can be achieved by running at low alumina contents in the bath. However, one might choose to sacrifice current efficiency in order to reduce harmful $\mathrm{PFC}$ emissions.

In 2014 Wong et al. [13] presented a work where they systematized some observations on anode effect (AE) in industrial cells. They listed three types of AE:

1. Conventional AE (high voltage).

2. Low voltage propagating AE (leads to high voltage AE).

3. Low voltage non-propagating AE.

The characteristic feature in the case ofitem 3 was that it could go on producing PFCs for a long period of time without triggering an AE. The reason given was poor distribution of alumina, and it was claimed that large cells with many anodes were particularly vulnerable.

The PFC emission has for a long time been a concern of the aluminium industry, and considerable efforts have been spent on this problem [1-16]. However, one should be aware of "similar" electrolytic processes that apply carbon anodes in fluoride melts may have related problems. For example, rare earth metals, e.g., neodymium, can be produced by dissolving their oxides in fluoride melts and performing electrolysis using carbon or graphite anodes. Keller and Larimer [17] studied electrowinning of 


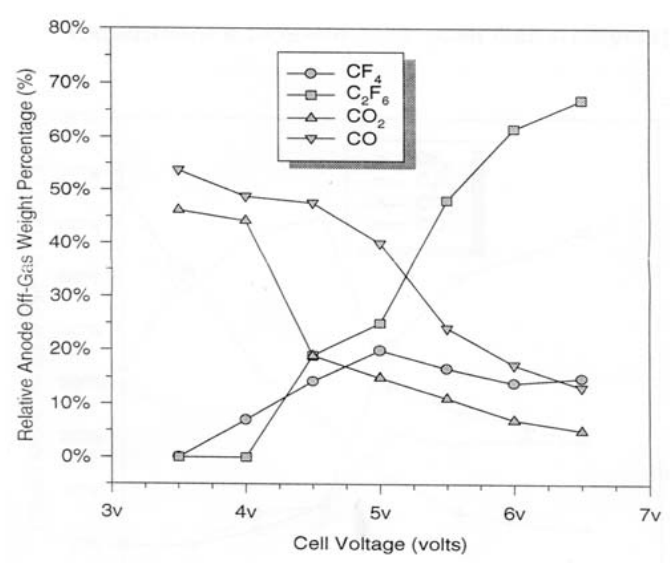

Fig. 3. The composition of gas coming off a graphite anode by electrowinningof neodymium from neodymium oxide dissolved in a fluoride melt (60 wt \% $\left.\mathrm{NdF}_{3}, 20 \mathrm{wt} \% \mathrm{CaF}_{2}, 10 \mathrm{wt} \% \mathrm{LiF}, 1 \mathrm{wt} \% \mathrm{Nd}_{2} \mathrm{O}_{3}\right)[18]$

neodymium from neodymium oxide in a fluoride melt. The composition of the anode gas coming off the graphite anode is shown in Fig. 3. A relatively high voltage (and current) produced high contents of $\mathrm{CF}_{4}$ - and hence it would require $\mathrm{NdF}_{3}$ to be added to a cell for industrial neodymium production. This situation can allegedlybe remedied by selecting a large anode surface area, thereby maintaining a low anodiccurrent density [18].

\section{Conclusions}

1. It appears that the phenomenon of low voltage PFC emissions can be understood on the basis of the critical current density being reached on one or more anodes that have been subjected to alumina depletion.

2. Ways should be found in order to reduce low voltage PFC emissions.

3. Procedures must be found on how to detect and monitor low voltage PFC emissions.

4. The observation of the absence oflow voltage PFC emissions on Soderberg cells should be further investigated. Is it universally true, and could the reason be associated with the fact that a Soderberg cell has only one anode?

\section{References}

1. Thonstad J., Fellner P., Haarberg G.M., Hives J. Aluminium Electrolysis. Fundamentals of the Hall-Heroult Process, Aluminium-Verlag, Dusseldorf, 2001.

2. Marks J., Bayliss C. GHG Measurement and Inventory for Aluminum Production. TMS Light Metals 2012. P. 805.

3. LiW., Chen X., Zhao Q., Qiu S., Zhang S.PFC Survey in Some Smelters of China.TMS Light Metals 2011. P. 357.

4. Li W., Chen X., Yang J., Hu C., Liu Y., Li D., Guo H.Latest Results from PFC Investigation in China.TMS Light Metals. 2012. p. 619.

5. Zarouni A.A., Zarouni A.A. DUBAL's Experience of Low Voltage PFC Emissions. 10th Australas.Aluminium Smelting Techn. Conf., Tasmania, Oct. 9-14, 2011. 
6. Tarcy G. Alcoa Tech. Center, 100 Technical Drive, PA 15069, Private communication.

7. Thonstad J., Nordmo F. Rodseth J.K. On the Anode Effect in Cryolite Melts - The Initiation of the Anode Effect, Electrochim. Acta. 1974. Vol. 19. P. 761.

8. Dorreen M.M.R., Chin D.L., Lee J.K.C., Hyland M.M., Welch B. Sulfur and Fluorine Containing Gases Produced during Normal Electrolysis and Approaching an Anode Effect. TMS Light Metals 1998. P. 311.

9. Marks J., Bayliss C. GHG Measurements and Inventory for Aluminum Production. TMS Light Metals 2012. P. 805.

10. Zarouni A., Reverdy A.L., Zarouni M.A., Venkatasubramanian K.A Study of Low Voltage PFC Emissions at Dubai. TMS Light Metals 2013. P. 859.

11. Wong D., Marks J. Continuous PFC Emissions Measured on Individual 400kA Cells. TMS Light Metals 2013. P. 865.

12. Chen X., Li W., Zhang Y., Qiu S., Bayliss C. Investigation on Formation Mechanism of NonAnode Effect Related PFC Emissions from Aluminum Reduction Cells. TMS Light Metals 2013. P. 877.

13. Wong D.S., Tabereaux A., Lavoie P. Anode Effect Phenomena during Conventional AEs, Low Voltage Propagating AEs \& Non-Propagating AEs. TMS Light Metals 2014. P. 529.

14. JassimA., Akhmetov S., Welch B. J., Skyllas-Kazacos M., Bao J. Yao Y. Studies on Background PFC Emission in Hall-Heroult Reduction Cell Using Online Anode Current Signals. TMS Light Metals 2015. P. 545.

15. Batista E., Dando N.R., Menegazzo N., Espinoza-Nava L. Sustainable Reduction of Anode Effect and Low Voltage PFC Emissions. TMS Light Metals 2016. P.537.

16. Evans J.W., Urata N. Wireless and Non-Contacting Measurement of Individual Anode Currents in Hall-Héroult Pots; Experience and Benefits. TMS Light Metals 2012. P. 939.

17. Keller R., Larimer K. Anode Effect in Neodymium Oxide Electrolysis, Rare Earth Science, Technology and Applications.TMS Annual Meeting 1997. P. 175.

18. Electrolytic Production of neodymium without perfluorinated carbon compounds on the offgases: Patent: No: 5810993 US // Keller R., Larimer K.T. EMEC Consultants; public date 1998. 